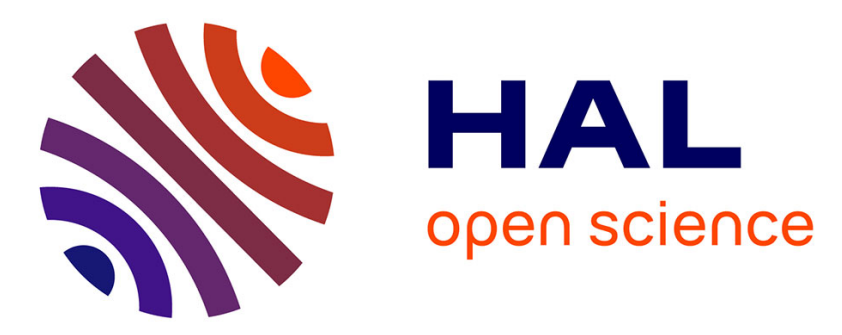

\title{
Modules of Stone Construction and the Building of Ritual and Social Traditions in Prehistoric Xinjiang (China) and Mongolia
}

\author{
Annie Chan
}

\section{- To cite this version:}

Annie Chan. Modules of Stone Construction and the Building of Ritual and Social Traditions in Prehistoric Xinjiang (China) and Mongolia. Asian Perspectives, 2020, 10.1353/asi.2020.0017 . hal03220937

\section{HAL Id: hal-03220937 \\ https://hal.science/hal-03220937}

Submitted on 7 May 2021

HAL is a multi-disciplinary open access archive for the deposit and dissemination of scientific research documents, whether they are published or not. The documents may come from teaching and research institutions in France or abroad, or from public or private research centers.
L'archive ouverte pluridisciplinaire HAL, est destinée au dépôt et à la diffusion de documents scientifiques de niveau recherche, publiés ou non, émanant des établissements d'enseignement et de recherche français ou étrangers, des laboratoires publics ou privés. 


\section{Modules of Stone Construction and the Building of Ritual and Social Traditions in Prehistoric Xinjiang (China) and Mongolia}

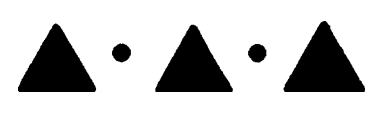

Annie CHAN

OVERVIEW

ORGANIZED CLUSTERS OF STONE STRUCTURES ARE A STARK and ubiquitous archaeological feature of the Inner Asian steppe. Diverse in form but rather homogenous in constructional concept, these built forms represent significant episodes of human activity, particularly in funerary and commemorative respects, from the beginning of the second millennium B.C.E. to late in the first millennium C.E. Interest in their distributional characteristics has stimulated a critical development in methods of spatial and statistical analysis tailored to the idiosyncrasies of prehistoric steppe landscapes, most notably through field studies of Bronze Age and Xiongnu sites in Mongolia (Allard and Erdenebaatar 2005; Brosseder and Miller 2011; Honeychurch et al. 2007; Houle 2010; Jacobson-Tepfer et al. 2010; Kovalev 2005), southern Siberia (Bourgeois et al. 2014; Kiryushin et al. 2015; Kiryushin et al. 2006; Plets et al. 2012; Tishkin and Gorbunova 2005), and, more recently, Xinjiang, China (Caspari; Chan and Cong, this issue).

Although such survey data have contributed to a more holistic view of longitudinal and spatial changes in the area (Caspari, this issue), scholars have rarely addressed data of a scope that traverses international boundaries. The difficulty of integrating crossregional studies can be attributed to linguistic barriers and disparities in research approach among different long-established academic traditions, some of which are represented by the authors in this special section. Naturally, such barriers have hindered the circulation and publication of primary field data. Zhang and Festa's well-referenced literature review ameliorates the problem by offering a rare background analysis useful for grasping the current modus operandi of archaeology in Xinjiang, especially for an English-speaking readership (also see Bennett 2012). Their article comprehensively outlines the key theories and methods of analysis underpinning the major discoveries and local research developments in Xinjiang archaeology from the 1950s through the 2000s.

Annie Chan (https://orcid.org/0000-0002-4435-3209) is Assistant Professor at the Institute of Sinology, Department of Asian Studies, Ludwig Maximilian University of Munich, and Foreign Associate Member at the East Asian Civilizations Research Centre (CRCAO), France. 
Paucity of excavation data is another important limitation, both because of the small number of excavations that have been carried out of, for example, Iron Age funerarycommemorative complexes in Mongolia (Tishkin, this issue) and Bronze Age settlement structures in Xinjiang (Caspari; Chan and Cong, this issue), and the scant availability of primary field data, which are often distributed only through local publications (see Zhang and Festa's Table 1 list of primary excavation reports, this issue). Previous ventures have shown that the translation and transference of such latent scholarly materials onto international publishing platforms have the potential to advance our collective understanding of the status of research in various fields (e.g., Bemmann et al. 2009; Brosseder and Miller 2011).

The idea of compiling such studies originated in a post-conference discussion following the Seventh Society for East Asian Archaeology meeting in Boston, Massachusetts in 2016. With the exception of Zhang and Festa's valuable later addition, the articles herein were developed from presentations given by the authors at a panel entitled "From the Tian Shan to the Altai: Recent advances in archaeological research." In presenting a selected body of primary field research conducted by Russian and Chinese teams in western Mongolia and Xinjiang on remains of ancient stonework, this special section aims to take a step toward building the representation of non-Western scholarship in more internationally accessible venues of publication, particularly those concerned with the archaeology of Inner Asia. The articles detail findings from field surveys and excavations as well as secondary literature that has hitherto largely been absent from the English language literature. This special section thus showcases the extent and value of a corpus of material that has yet to be assimilated into mainstream discourse.

The areas of study encompass several important geographical nuclei of archaeological sites, including the western peripheries of Dzungaria and the Chinese Tian Shan and, further east, the regions of the Chinese and Mongolian Altai. Three articles report on field expeditions in Xinjiang (Caspari; Chan and Cong; Zhang and Festa) and one in Mongolia (Tishkin). The authors address findings spanning a period from the middle of the Bronze Age to the Iron Age (covering the second through first millennia B.C.E.), with a focus on burial and non-burial stone structures, stelae, and the burial goods with which they are associated.

\section{MODULES AND AESTHETICS OF STONE CONSTRUCTION AND SPATIAL} RECONSTRUCTIONS OF FUNERARY AND COMMEMORATIVE CULTURES

The ways in which archaeological studies of stone structures in Xinjiang and Mongolia have been conducted fall into two broad types of assessment: qualitative and quantitative. The former focuses on structural form and schematic design and interprets traits in funerary and commemorative architecture as distinctive representations of culture, while the latter deduces function and distribution by detecting behaviorally meaningful patterns from the quantification of archaeological features on a multi-sited or pan-regional scale.

The outcome of qualitative assessments of the archaeological record is often the formulation of typologies based on a combination of formal characteristics attributable to existing or new archaeological cultures. Although Chan and Cong's article on architectural landscapes in Bortala and Ili valleys in Xinjiang leans on research of the classification of Bronze Age Andronovo Culture, it advocates a contextualized view of 
the evidence by considering the features and principles of space use and building style against environmental and social conditions within defined geographical scopes. It furthermore highlights the unique processes of construction by which a structure may be distinguished into staggered, cumulative, or overlapping spatio-temporal stages of construction.

Similarly assessing the cultural significance of the Andronovo is Zhang and Festa's review of archaeological research in the Ili region. Throughout their article, they commend Chinese researchers for their fervent attempts at systematizing new findings from Ili and connecting Xinjiang to Central Asia by identifying possible relations between the Andronovo and Saka archaeological cultures. However, they also note that no behavioral inferences are drawn in many of these studies. This analytic gap is yet to be addressed in full, largely because of the lack of integration of middle-range theories, that is, inferential models commonly grounded in ethnographic, historical, and experimental studies that archaeologists use to connect data from field studies to general phenomena. Current researchers appear to emphasize the integration of new scientific methods of analysis, especially using digitization and imaging tools to improve cultural typologies, while overlooking questions regarding patterns of human behavior or adaptations to the environment.

When combined with quantitative analyses, developing typologies of prehistoric structures based on surface outlines nonetheless remains effective in delineating broad regional trends. Caspari's quantitative study of structures in Heiliutan Basin illustrates the diachronic and spatial changes in commemorative and habitational building practices in southern Kanas (Altai Prefecture, Xinjiang) over four millennia. His research covers a broad spectrum of structure types in the region. Relying on ground survey alone, he identifies 12 "monument" types and their respective frequencies and patterns of distribution. This is a similar approach to that taken by Bourgeois and colleagues (2014) in their survey of Dzhazator Valley in the Russian Altai. Caspari points out the difficulty of distinguishing some structural components and cluster boundaries based on surface features alone and remarks on the relative visibility of certain structural types.

Though not often outlined in official reports, inherent sampling and site delineation biases are a known conundrum in regional spatial studies of steppe landscapes (Honeychurch et al. 2007; Markofsky 2013). This affects not only how large-scale survey data are used as proxies for measuring changes in social organization and patterns of mobility and settlement, but also whether the selected variables are viable units of comparison. A holistic approach to ground survey, as Caspari advocates, is not always feasible since access is interdicted for certain areas near the border region. There is also the prevalent problem of looting throughout the region. In the case of Xinjiang and Mongolia, the statistics are further skewed by the disproportionate number of burial and commemorative sites being discovered compared to settlements, for which there have been scant archaeological data until recently (see Tishkin; Zhang and Festa, this issue).

The strong geometric homogeneity of the surface features further challenges any attempt at establishing a chronology based on arbitrary structure types that can be tested on a cross-regional scale. The key to a more empirical system of classification could be found beneath the ground surface. Results of excavations at Aduuchuluu and Husita in Bortala River Valley and Jirentai in Ili River Valley show that the subterranean parts of non-burial structures are often more complex than surface 
features suggest and therefore reveal a far more reliable architectural schema with which to distinguish structural differences (Chan and Cong, this issue). It is by studying variations in subterranean features - postholes, hearths, and wall foundations - that the design and functional differences between Ili and Bortala's Bronze Age "double-walled dwellings" are made clear. For instance, a consecutive pattern of construction is unique to the habitation structures so far investigated in Bortala. A single enclosure or complex can be made up of building components that date to different periods of construction. This is because components of earlier constructions were often adapted for building an extension during a later period of site reoccupation. This building practice is also observed in burial structures, many of which consist of modules successively appended to an initial construction. In Ili, by contrast, building designs incorporate regular arrangements of hearths and postholes and evince extended periods of occupation. A more centralized social organization is also represented by the coexistence of the various structures used for habitation, burial, and specialized activities in the same location.

Other surface objects associated with these structures possess artistic and stylistic traits that can be used to characterize funerary and commemorative cultures. Deer stones, for example, are integral to the ritual composition of khirigsuurs and the iconography of their bas-relief conveys past perceptions of the physical and spiritual worlds. Images depicting armaments could be suggestive of the prevalence of warfare or homage to military might (Fitzhugh 2009a; IAX CASS et al. 2016; Volkov 2002). It has been argued that zoomorphic motifs are a manifestation of animistic beliefs and shamanistic devices traditionally deployed in hunting rituals (Fitzhugh 2009a, 2009b, 2010; Jacobson-Tepfer 2015; Pan 2008). Tishkin gains new insight from a study of the relief contours of deer stones in Buyant Valley. He argues that understanding how carving techniques play into pictorial composition is key to identifying designs on a stele. Improving rubbing techniques is therefore crucial to reading deer stone imagery. By tracing the profile of the chiseled surfaces on the deer stones, Tishkin identifies depictions of headdresses and other sartorial features at his study site. He also notices that there is a correlation between pictorial representations and the physical characteristics (i.e., the size and profile) of the deer stones. For example, the "combat belt" is only found on large deer stones. Tishkin further illustrates the distinct carving techniques of deer stones by comparing them to medieval Turkic anthropomorphic statues of the mid-fifth through eleventh centuries C.E., which are primarily distributed across Mongolia, southern Siberia, Inner Mongolia, and Xinjiang (Hayashi 2005; Ren 2013; Wang and Qi 1995). Representations of weaponry and certain sartorial details remained in the Turkic period, but the sculptural presentation of stone stelae evolved as it became modeled on more three-dimensional forms.

The commemorative building practice of putting up deer stones and khirigsuurs (a Late Bronze Age funerary or commemorative structural complex consisting of a central mound enclosed by a circular or quadrangular fence, clusters of auxiliary stone circles on the perimeter, and occasionally radial pavements) is also found on the other side of the Altai Mountains across the China-Mongolian border. Altay 阿勒泰 Prefecture has the highest concentration of deer stones in Xinjiang, with 72 deer stones and 34 sites documented to date; a total of 27 deer stones and 16 sites have been recorded from the rest of Xinjiang (Xinjiang Cultural Bureau 2011:151). However, the existence of deer stones and khirigsuurs in Xinjiang and their connection to coeval funerary and ritual cultures remain poorly understood despite the excavations of mega-complexes such as 
at Sandaohaizi 三道海子 site (IAX CASS et al. 2016; Wright 2012:139, 141, 151; XIA 2014). Comprising ca. 100 stone mounds across an area of nearly $600 \mathrm{~km}^{2}$, among which are three of the largest stone mounds discovered in the Chinese Altai, Sandaohaizi is unique for its scale. The recent excavation of mound no. 1 at one of the sites, Huahaizi 花海子, a half-submerged flat-stone barrow of a cross-spoke design, yielded radiocarbon dates from the ninth century B.C.E. Other than two deer stones and fragments of ceramics and animal bones in the auxiliary sacrificial stone circles, however, material finds are scarce. Further studies of other complexes in the region are needed to better understand the chronological, stylistic, and functional connections between khirigsuurs and deer stones in Xinjiang with their counterparts in Mongolia and southern Siberia in late prehistory (Guo 2011; Kovalev and Erdenebaatar 2007; Pan 2008).

\section{FUTURE DIRECTIONS}

Moving forward, a vital task appears to be continuing to consolidate dispersed datasets currently subsumed under different research traditions. To do so, it is also necessary to devise more inclusive and multilingual collaborative frameworks for data exchange. This would help us better integrate disparate systems of classification and unite separate discourses. This entails a methodological approach that takes into account not only variability in structural form but also time scale of construction and history of use. The prescribed criteria for organizing structures into cultural types are generally applicable to aboveground building features alone, but they are not incontrovertible chronological or cultural markers. Without excavation, a Turkic burial mound can easily be mistaken for an Iron Age cairn. A Bronze Age quadrilateral habitation structure might have been reconfigured during constructions dating to a much later time period. It is of course an almost impossible task to synchronize the many cultural typologies that originated in different parts of the region into one overarching classificatory system, but it is possible to redirect questions of social change and complexity to scopes of analysis independent of prescribed "types." Previous studies have already made considerable progress in developing methods of spatial analysis that are most appropriate for quantifying and periodizing a diffuse monumental landscape with great social variation (Allard and Erdenebaatar 2005; Honeychurch et al. 2007; Wright 2012). A multivariate approach to diagnosing the nature of site use in pastoral landscapes, for example, may elucidate the factors at play and their variability (Wright 2017).

A relatively untapped source for identifying and testing such factors is the cultural knowledge of the conceptualization of space from ethological studies. It has been widely documented that burials and commemorative places are spatial markers that originate in sacralized views of the human relationship to the physical elements of the environment and are then used in the symbolic zoning of a landscape (Sodnompilova and Nanzatov 2019). The scale, orientation, and location of a habitation or a burial are not solely determined by an unvarying set of factors based on subsistence practices or social customs. As a building project is formulated within the composite whole that is the landscape, its spatial qualities must be viewed as interdependent and perpetuating.

The perpetuation of certain building characteristics over time has been observed in the archaeological record. The temporality of sites and structures is thus a pivotal trait that determines architectural and spatial configurations. Two structural entities of the same form could have been constructed on different timescales. That is, they may 
contain building elements (even stelae such as deer stones) that have been reused, repurposed, redesigned, and expanded upon over time. It is also common in Inner Asian steppe to find aboveground structural remains of an amalgamation of building elements from completely different cultural periods. Such staggered phases of construction generate a discontinuous stratigraphy of time-depth for the archaeological site that surface typologies simply cannot represent. The accumulated building heritage of a site is echoed in formal continuity of burial architecture over time and across generations. Identifying intra-site temporal spectrums and spatial connectivities between different architectural and cultural periods is central to defining the social customs of stone architecture of the Inner Asian steppe.

\section{REFERENCES CITED}

Allard, Francis, and Dimmajay ErdenebaAtar

2005 Khirigsuurs, ritual and mobility in the Bronze Age of Mongolia. Antiquity 79:547-563.

Bemmann, Jan, Hermann Parzinger, Ernst Pohl, and D. Tseveendorzh, eds.

2009 Current Archaeological Research in Mongolia. Bonn: Vor-und Frühgeschichtliche Archäologie Rheinische Freidrich-Wilhelms-Universität.

BenNetT, Gwen

2012 National history and identity narratives in the People's Republic of China: Cultural heritage interpretation in Xinjiang, in The Archaeology of Power and Politics in Eurasia: Regimes and Revolutions: 37-56, ed. Charles W. Hartley, G. Bike Yazicioglu, and Smith Adam. Cambridge, UK: Cambridge University Press.

Bourgeois, J., D. V. Cheremisin, G. Plets, E. P. Dvornikov, A. V. Ebel, B. Stichelbaut, L. van Hoof, AND W. GHEYLE

2014 An archaeological landscape in the Dzhazator Valley (Altai Mountains): Surface monuments and petroglyphs from the Chalcolithic to the Ethnographic Period. Archaeology, Ethnology and Anthropology of Eurasia 42(4):106-119.

Brosseder, Ursula, and Bryan K. Miller

2011 State of research and future directions of Xiongnu studies, in Xiongnu Archaeology: Multidisciplinary Perspectives of the First Steppe Empire in Inner Asia, ed. Ursula Brosseder and Bryan Kristopher Miller. Bonn Contributions to Asian Archaeology, vol. 5. Bonn: Vor-und Frühgeschichtliche Archäologie Rheinische Freidrich-Wilhelms-Universität.

Fitzhugh, William.

$2009 a$ Pre-Scythian ceremonialism, deer stone art, and cultural intensification in northern Mongolia, in Social Complexity in Prehistoric Eurasia: Monuments, Metals and Mobility: 378-411, ed. Bryan K. Hanks and Katheryn M. Linduff. Cambridge: Cambridge University Press.

$2009 \mathrm{~b}$ Stone shamans and flying deer of northern Mongolia: Deer goddess of Siberia or chimera of the steppe? Arctic Anthropology 46(1-2):72-88.

2010 The Mongolian deer stone-khirigsuur complex: Dating and organization of a Late Bronze Age menagerie, in Current Archaeological Research in Mongolia, Vor-und Frühgeschichtliche Archäologie: 183-199, ed. Jan Bemmann, Hermann Parzinger, Ernst Pohl, and Damdinsuren Tseveendorzh. Bonn: Rheinische Friedrich-Wilhelms-Universität.

GUO Wu 郭物

2011 Xinjiang shiqian wanqi shehui de kaogu yanjiu 新疆史前晚期社會的考古研究 [Archaeological Research of Late Prehistoric Societies in Xinjiang]. Shanghai: Shanghai guji chubanshe 上海古 籍出版社.

HAYASHI TOSHIO 林俊雄

2005 Yürashia no ishi hito ユーラシアの石人 [Anthropomorphic Statues of Eurasia]. Yūrashia kōkogaku sensho ユーラシア考古学選書 [Selected Books in Eurasian Archaeology]. Tokyo: Yuzankaku.

Honeychurch, William, Joshua Wright, and Chunag Amartuvshin

2007 A nested approach to survey in the Egiin Gol Valley, Mongolia. Journal of Field Archaeology 32:369-383. 
Houle, JEAN-LuC

2010 Emergent Complexity on the Mongolian Steppe: Mobility, Territoriality, and the Development of Early Nomadic Polities. Ph.D. thesis. University of Pittsburgh.

Iax Cass, Aletai, and Qinghe [Zhongguo shehuikeXueyuan KaOgu yanjiusuo Xinjiang gongzuodui 中 國社會科學院考古研究所新疆工作隊 (Institute OF ARChAEOlogy Xinjiang Excavation Team, Chinese Academy of Social Sciences), Aletai diqu wenwuju 阿勒泰地區文物局 (Altai Prefectural Bureau of Cultural Relics), And Qinghe Xian wenwuju 青河縣文物局 (Qinghe County Bureau of Cultural Relics)]

2016 Xinjiang Qinghe-xian Huahaizi sanhao yizhi fajue jianbao 新疆青河縣花海子三號遺址發掘 簡報 [The preliminary excavation report of site no. 3 at Huahaizi, Qinghe County, Xinjiang]. Kaogu 考古 9:25-37.

JACOBSON-TEPFER, ESTHER

2015 The Hunter, the Stag, and the Mother of Animals. Image, Monument, and Landscape in Ancient North Asia. New York: Oxford University Press.

Jacobson-Tepfer, Esther, James E. Meacham, and Gary Tepfer

2010 Archaeology and Landscape in the Mongolian Altai: An Atlas. Redlands, CA: ESRI Press.

Kiryushin, Yu. F., D. V. Papin, And O. A. Fedoruk

2015 Andronovskaya kul'tura na Altaye (po materialam pogrebal'nykh kompleksov) [Andronovo Culture in the Altai (according to the materials of the burial complexes)]. Barnaul: Altai State University Publishing House.

Kiryushin, Yu. F., O. A. Pozdnyakova, D. V. Papin, and A. B. Shamshin

2006 Kollektsiya metallicheskikh ukrashe- niy iz pogrebeniy andronovskogo kompleksa mogil'nika Rublevo-VIII [Collection of metal ornaments from the burials of the Andronovo complex of the Rublevo-VIII burial ground], in Altay $v$ sisteme metallurgicheskikh provintsiy bronzovogo veka [Altai in the System of Bronze Age Metallurgical Provinces]: 33-45. Barnaul: Altai State University Publishing House.

Kovalev, A. A.

2005 Chemurchekskiy kul'turnyy fenomen: yego proiskhozhdenne i rol' v formirovanii kul'tur zpokhi ranney bronzy Altaya i Tsentral'noy Azii [The cultural phenomenon of Chemurchek: Its origin and role in the formation of cultures in the Early Bronze Age of the Altai and Central Asia], in Zapadnaya i Yuzhnaya Sibir'v drevnosti: Sbornik nauchnykh trudov, posvyashchennyy 60letiyu so dnya rozhdeniya Yuriya Fedorovicha Kiryushina [Western and Southern Siberia in Antiquity: Collection of Scientific works dedicated to the 60th Anniversary of the Birth of Yuri Fedorovich Kiryushin]: 178-184. Barnaul: Altai State University Press.

Kovalev, A. A., and D. Erdenebaatar

2007 Dve traditsii ritual'nogo ispol'zovaniya olennykh kamney Mongolii [Two traditions of ritual use of deer stones of Mongolia], in Kamennaya skul'ptura $i$ melkaya plastika drevnikh $i$ srednevekovykh narodov Evrazii [Stone Sculpture and Small Sculptures of Ancient and Medieval Peoples of Eurasia]: 99-105. Barnaul: Azbuka.

MARKOFSKY, STEVEN

2013 When survey goes east: Field survey methodologies and analytical frameworks in a Central Asian context. Journal of Archaeological Method and Theory 21(4):697-723.

PAN LING 潘玲

2008 Lun lushi de niandai ji xiangguan wenti 論鹿石的年代及相關問题 [On the date of deer stones and related problems]. Kaogu xuebao 考古學報 3:311-386.

Plets, Gertjan, Wouter Gheyle, Geert Verhoeven, Jeroen De Reu, Jean Bourgeois, Jeroen Verhegge, and Birger Stichelbaut

2012 Three-dimensional recording of archaeological remains in the Altai Mountains. Antiquity 86:884-897.

REN BAOLEI 任寶否

2013 新疆地區的突厥遺存與突厥史地研究. Ph.D. diss. Northwest University 西北大學, Xi'an, China.

Sodnompilova, Marina M., and Bair Z. Nanzatov

2019 The idea of space among the nomads of Great Steppe. Social Evolution and History 18(2):35-54.

Tishrin, A. A., And T. G. Gorbunova

2005 Rekonstruktsiya uzdechek mnozhestv bulan-kobinskoy kul'tury (po materialam pamyatnika Yalomanu-II) [Reconstruction of the bridle sets of the Bulan-Koba culture (according to the 
materials of the monument Yaloman-II)], in Oborudovaniye kochevnikov Yevrazii [Equipment of the Nomads of Eurasia]: 118-122. Barnaul: Altai State University Publishing House.

Volkov, V. V.

2002 Olennye kamni Mongolii [Deer Stones of Mongolia]. Moscow: Nauchnyy mir.

WANG BO 王博 AND QI XIAOSHAN 祁小山

1995 Xinjiang shiren de leixing fenxi 新疆石人的類型分析 [A typological analysis of anthropomorphic statues in Xinjiang]. Xiyu yanjiu 西域研究 4:67-76.

WRIGHT, JOSHUA

2012 Landscapes of inequality? A critique of monumental hierarchy in the Mongolian Bronze Age. Asian Perspectives 51(2):139-163.

2017 Describing microenvironments used for nomadic pastoralist habitation sites: Explanatory tools for surfaces, places, and networks, in The Archaeology of Human-Environment Interactions. Strategies for Investigating Anthropogenic Landscapes, Dynamic Environments, and Climate Change in the Human Past: 211-228, ed. Daniel A. Contreras. Routledge Studies in Archaeology. New York: Routledge.

XIA [XINJIANG WENWU KAOGU YANJIUSUO 新疆文物考古研究所 (XINJIANG INSTITUTE OF ARCHAEOLOGY)]

2014 Bu'erjin-xian Kanasi xiahukou Tuwaxincun gumudi kaogu fajue jianbao 布爾津縣喀納斯下 湖口吐瓦新村古墓地考古發掘簡報 [A preliminary excavation report of Tuwaxincun Cemetery in Bu'erjin County]. Xinjiang Wenwu 新疆文物 2:60-74.

Xinjiang Cultural Bureau [Xinjiang Weiwu'er Zizhiqu Wenwuju 新疆維吾爾自治區文物局 (Xinjiang Uyghur Autonomous Region Bureau of Cultural Relics)]

2011 Xinjiang caoyuan shiren yu lushi:Xinjiang weiwu'er zizhiqu disanci quanguo wenwu pucha chengguo jicheng 新疆草原石人與鹿石: 新疆維吾爾自治區第三次全國文物普查成果集成 [Anthropomorphic Statues and Deer Stones of the Xinjiang Steppe: A Compendium of the Results of the Third National Survey of Cultural Relics in Xinjiang Uyghur Autonomous Region]. Beijing: Kexue chubanshe 科學出版社. 